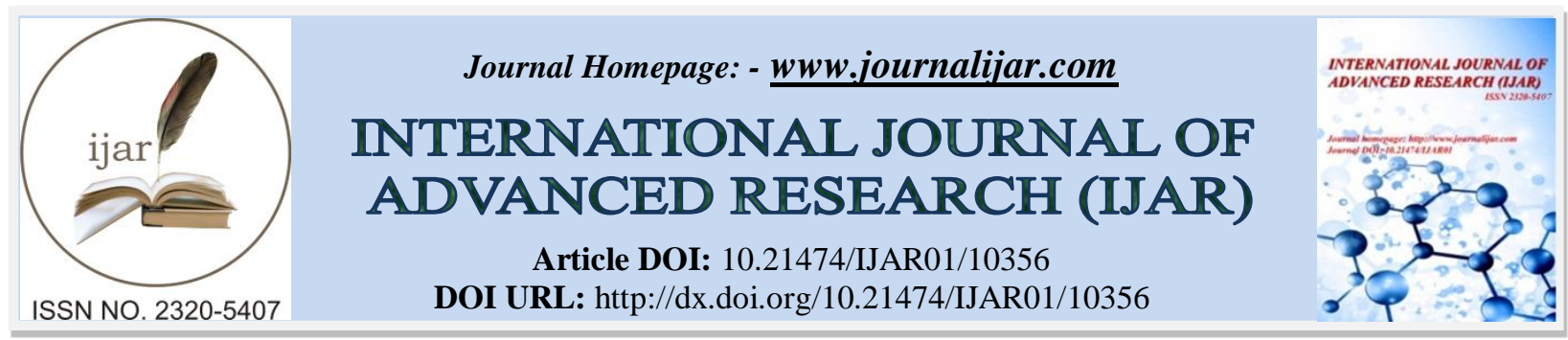

RESEARCH ARTICLE

\title{
EXPOSURE TO FLUORIDE SIGNIFICANTLY DECREASE THE CELL MEMBRANE INTEGRITY AND MITOCHONDRIAL ACTIVITY IN MURINE RENAL CELLS
}

\author{
Thanusha Perera ${ }^{1}$, Kasun Godakumara ${ }^{1}$, Shirani Ranasinghe ${ }^{1,2}$ and Neil Alles ${ }^{2}$ \\ 1. Postgraduate Institute of Science, University of Peradeniya, Sri Lanka. \\ 2. Department of Biochemistry, Faculty of Medicine, University of Peradeniya, Sri Lanka.
}

\section{Manuscript Info}

.1........................

Manuscript History

Received: 30 November 2019

Final Accepted: 31 December 2019

Published: January 2020

Key words:-

Fluoride Toxicity, Kidney Disease Of Unknown Etiology (Ckdu), Sri Lanka, Kidney Cell Culture, Mitochondria

\section{Abstract}

Background: Kidney Disease of unknown etiology (CKDu) in Sri Lanka is not related to the diabetes-related kidney damage but the extensive contamination of groundwater by fluoride was one of the main suspected reasons for the crises. Therefore, the aim of this study was to determine the effect of fluoride on kidney cell viability with exposure to increasing concentrations of fluoride for different duration of time periods.

Method: Kidneys from four weeks old mice were removed aseptically and cultured with $\alpha$-MEM media supplemented with $10 \%$ fetal bovine serum (FBS) and 1\% Penicillin / Streptomycin solution, overnight incubation at $370 \mathrm{C}$ in a $\mathrm{CO} 2$ incubator. After 2 days, cells were divided into $0.5 \times 106$ cells $/ 25 \mathrm{~cm} 2$ culture flasks and $1 \times 104$ cells/ well in 96-well plates. Culture flasks were treated with Sodium fluoride $(\mathrm{NaF})$ at concentrations of $0.125,0.25,0.5,1,2,4$ and $8 \mathrm{mM}$ for $12 \mathrm{hr}$ and the viable cell number was calculated by trypan blue assay. Then 96-well plates were exposed to same concentrations of NaF for 12 - 36 $\mathrm{hr}$ and mitochondrial activity was evaluated by using 3-(4,5dimethylthiazol-2-y1)-2,5-diphenyl tetrazolium bromide (MTT) assay.

Results: Renal cell damage was significantly decreased at 1, 2, 4 and $8 \mathrm{mM} \mathrm{NaF}$ concentrations compared to control group with $20.13 \%$, $28.5 \%, 30.88 \%$ and $38.45 \%$ respectively. The mitochondrial activity of renal cells showed a significant decrease at $8 \mathrm{Mm} \mathrm{NaF}$ concentration after $12 \mathrm{~h}$. Moreover, by increasing the incubation time from 12 to $24 \mathrm{~h}$ and $36 \mathrm{~h}$, the mitochondrial activity was further decreased at 2, 4 and $8 \mathrm{mM} \mathrm{NaF}$ at $24 \mathrm{~h}$ and $0.5,1,2,4$ and $8 \mathrm{Mm} \mathrm{NaF}$ at $36 \mathrm{~h}$ with respect to control groups.

Conclusion: Fluoride exposure resulted renal cell damage and concentration dependent decrease in mitochondrial activity with increased exposure time.

Copy Right, IJAR, 2020,. All rights reserved.

\section{Introduction:-}

Diabetes and hypertension are the major related clinical problems in the patients with chronic kidney disease (CKD), but in Sri Lanka, it was reported that CKD of unknown cause was associated with neither diabetes nor hypertension [1-3]. Therefore, it is designated as Chronic Kidney Disease of Unknown Etiology (CKDu) [4-6]. This disease involves slow, asymptomatic progressive kidney damage and nearly $80 \%$ of patients undergo total kidney failure 
within 2 years following diagnosis. Lack of clinical symptoms until late stages makes diagnosis and treatment complicated. Therefore end-stage kidney disease usually ends with kidney dialysis or organ transplant for patients to survive [7]. According to the health statistics there are 2,000 CKDu related deaths annually [8] and number of patients increases nationwide throughout disease progression. Government requires spending high economic cost approximately $4 \%$ of the annual health budget for dialysis and other medications to the patients [9].

The initiating causes of CKDu are highly variable and epidemiological studies reveal a number of risk factors for $\mathrm{CKDu}$, such as high fluoride levels in water [10-11], soil-geochemistry [12] and environmental pollution [13]. The pathological characteristics of CKDu are tubulointerstitial damage, interstitial fibrosis and tubular atrophy [14-17]. However, no matter the cause, the progressive structural changes that occur in the kidney are characteristically unifying.

The kidney is a highly energetic organ and rich in mitochondria [18-19]. The number of mitochondria distributed in cells varies greatly, ranging from $\sim 16$ in human germ cells to 100,000 in oocytes [20-21], depending on the distinct energy demands of the respective cells and energy is found mainly in the form of adenosine triphosphate (ATP) $[19,22]$. Tubular cells are engaged in many important cellular ion transport mechanisms consuming much energy and are having high metabolic rates enriched with rich in mitochondria [23-24]. Thus mitochondrial dysfunction in these functional cells plays a critical role in the kidney diseases [18] and renal disorders related to the mitochondrial cytopathies, have been recorded including proximal tubulopathy, proximal tubular acidosis with several symptoms like hypermagnesuria, proteinuria, nephrotic syndrome, tubulointerstitial nephritis and renal failure [22].

The number of living cells can be assessed by Trypan blue assay, a dye exclusion staining assay, which is based on entry of trypan blue dye into the dead cells. This concept can be used to assess the cell viability which is highly adopted by the cell membrane integrity, as viable cells are not permeable to this dye [25]. So the viable cell will have a clear cytoplasm whereas a nonviable cell will have a blue cytoplasm [26]. The mitochondrial activity in living cells can be evaluated by 3-(4,5-dimethylthiazol-2-y1)- 2,5-diphenyl tetrazolium bromide (MTT) assay which depends on the capacity of mitochondrial dehydrogenase activity in living cells to change over the yellow substrate MTT into a dull blue formazan $[18,27]$. This formazan formation can be quantified by spectrophotometrically and serves as an estimate of the activity of mitochondria [28-29] and hence the number of living cells in the sample [30].

Though there were many suspected etiological factors such as fluoride, heavy metals and agrochemicals for the disease with unknown etiology, no clear evidence or a mechanism has been proven the etiologies as well as assess the impact on renal cellular changes. Further, high content of fluoride has been reported in CKDu endemic areas $[10,11,31]$. Therefore, it was focused on fluoride, as one of the major suspected etiological factor due to a possible risk of damaging kidneys with a high exposure of fluoride as the kidneys are the major route of excretion of fluoride from the body [32-33]. Therefore, in this study we used $0.125,0.25$ and $0.5 \mathrm{mM}$ fluoride concentrations which were in the range of commonly reported high fluoride levels in CKDu endemic areas and 1,2, 4 and 8mM fluoride concentrations to represent considerable high fluoride levels used in other fluoride base studies.

Taken together, this study was designed to elucidate cell membrane integrity and mitochondrial activity by exposing murine renal cells to different concentrations of fluoride.

\section{Method:-}

Cell culture:

Kidneys from four weeks-old male ICR mice (origin; Clea Japan, Inc.), purchased from Medical Research Institute, Sri Lanka were removed aseptically and washed with phosphate buffers saline (without $\mathrm{Ca}^{2+} / \mathrm{Mg}^{2+}$, with $1 \%$ Penicillin / Streptomycin solution) (PBS, Sigma, St. Louis, USA) and alpha modified Minimum Essential medium ( $\alpha$-MEM, Gibco, Dublin, Ireland) supplemented with 1\% Penicillin / Streptomycin solution (Sigma, St. Louis, USA). They were minced into $1 \mathrm{~mm}$ pieces and digested with $0.1 \%$ collagenase Type I (Gibco, Dublin, Ireland) and $0.2 \%$ dispase II (Sigma, St. Louis, USA) at $37^{\circ} \mathrm{C}$ for 20 minutes. The isolated cells were then collected by centrifugation at $4^{0} \mathrm{C}$, $1500 \mathrm{rpm}$ for $5 \mathrm{~min}$ and disseminated in alpha modified Minimum Essential medium ( $\alpha$-MEM) supplemented with $10 \%$ fetal bovine serum (FBS, Gibco, Dublin, Ireland) and 1\% Penicillin / Streptomycin solution. They were transferred into $75 \mathrm{~cm}^{2}$ culture flask and incubated at $37^{\circ} \mathrm{C}$ in $5 \% \mathrm{CO}_{2}$ and the medium was changed $2^{\text {nd }}$ day after seeding and subsequently on every $3^{\text {rd }}$ day. When the cell density reached approximately $80 \%$ confluence, media was removed and the adhering cells were washed with PBS without $\mathrm{Ca}^{2+} / \mathrm{Mg}^{2+}$. Three milliliter of Trypsin/EDTA solution (Gibco, Dublin, Ireland) was added to the culture flask and incubated for $4 \mathrm{~min}$ at $37^{\circ} \mathrm{C}$ to detach the cells. Once cells 
have detached, the detached cell suspension was collected into a 50ml tube on ice which containing $3 \mathrm{ml}$ of FBS to inhibit further Trypsin activity. Furthermore cell layer was rinsed with PBS to dislodge any remaining adherent cells and total cell suspension was centrifuged at 1500rpm for $5 \mathrm{~min}$ at $4{ }^{\circ} \mathrm{C}$ and cell pellet was resuspended with $\alpha-\mathrm{MEM}$ medium (with 10\% FBS and 1\% Penicillin / Streptomycin solution). Finally, the cells were divided into two portions - one for the culture flasks and the other for the plates.

\section{Evaluation of viable cell count:}

Trypan blue (Sigma, St. Louis, USA) test was performed, in order to determine the number of viable cells present in a cell suspension based on their membrane integrity [26]. Cells were seeded in eight $25 \mathrm{~cm}^{2}$ culture flasks at $0.5 \times 10^{6}$ cells $/ 25 \mathrm{~cm}^{2}$ flasks with a total volume of $5 \mathrm{ml}$ of medium and incubated at $37^{0} \mathrm{C}$ in a $\mathrm{CO}_{2}(5 \%)$ incubator. After $24 \mathrm{~h}$, the medium was changed and one flask named as the control to which $\alpha$-MEM media without Sodium fluoride (NaF, Sigma, St. Louis, USA) was added, and to the other flasks, $\alpha$-MEM media containing NaF at final concentrations of $0.125,0.25,0.5,1,2,4$ and $8 \mathrm{mM}$ were added as test groups for further $24 \mathrm{~h}$ of incubation at $37^{0} \mathrm{C}_{\text {in }} 5 \% \mathrm{CO}_{2}$. Following $24 \mathrm{~h}$ incubation, the cells in each culture flask were rinsed twice in PBS without $\mathrm{Ca}^{2+} / \mathrm{Mg}^{2+}$, trypsinized for 4 min with $3 \mathrm{ml}$ of trypsin-EDTA solution at $37^{0} \mathrm{C}$ and cell suspension was collected into a 50ml tube on ice which containing $3 \mathrm{ml}$ of FBS. Then the flask was again washed with PBS and total cell suspension was centrifuged at $1500 \mathrm{rpm}$ for $5 \mathrm{~min}$ at $4^{\circ} \mathrm{C}$. Cell pellet was resuspended with $1 \mathrm{ml}$ of PBS and the viable cell number was calculated by trypan blue exclusion assay using haemocytometer. Ten microliter of $0.4 \%$ trypan blue and $90 \mu 1$ cell suspension were mixed well and kept for 5 min before loading into the hemacytometer. Ten microliter of cells from each mixture was loaded to the hemacytometer and total number of viable (unstained) and dead cells (stained) were recorded using a microscope. This was repeated three times and the percentages of viable cells were calculated as follow:

$\%$ viable cells $=($ Number of viable cells $/$ Total number of cells $) \times 100$

\section{Evaluation of activity of mitochondria:}

Further mitochondrial activity was evaluated by using MTT (Sigma, St. Louis, USA) assay with some modifications [27]. In brief, three 96 well plates, each with 8 replicates with 6 wells per group at a density of $1 \times 10^{4}$ cells/100 $\mu$ l $\alpha$ MEM media/well were incubated overnight at $37^{0} \mathrm{C}$ in a $\mathrm{CO}_{2}(5 \%)$ incubator. In each plate, first group served as control and treated with $\alpha$-MEM medium alone. Rest of the seven groups were treated with $\alpha$-MEM media containing $\mathrm{NaF}$ at final concentrations of $0.125,0.25,0.5,1,2,4$ and $8 \mathrm{mM}$. Plates were incubated for different incubation periods of 12,24 and $36 \mathrm{hr}$ at $37^{\circ} \mathrm{C}$ in a $5 \% \mathrm{CO}_{2}$. At the end of respective incubation periods, the media were removed completely and $10 \mu 1$ of MTT dye $(5 \mathrm{mg} / \mathrm{ml})$ was added to the each well and the plates were incubated again at $37^{\circ} \mathrm{C}$ in a $5 \% \mathrm{CO}_{2}$. After $4 \mathrm{hr}, 100 \mu \mathrm{l}$ of $100 \%$ Dimethyl sulfoxide (DMSO, Sigma, St. Louis, USA) was added to all the wells and left for $10 \mathrm{~min}$ at room temperature, the optical density (OD) in each well was detected at $570 \mathrm{~nm}$ by using ELISA plate reader (Human ELISA Reader, Germany). The percentage cell viability was calculated as follow:

$$
\% \text { cell viability }=(\mathrm{OD} \text { of treated } / \mathrm{OD} \text { of control }) \times 100
$$

\section{Statistical analysis:}

All the data were presented as mean \pm S.D and analyzed using one-way analysis of variance (ANOVA) and Fisher's multiple comparison tests. Results were declared significant at $\mathrm{p}<0.05$

\section{Results:-}

\section{Fluoride induce concentration dependent renal cell damage:}

Cell membrane integrity is a basic criterion for distinguishing dead cells from live cells [34]. Therefore we have first assessed whether fluoride exposure induce any renal cell damages by using Trypan blue exclusion staining which measures membrane integrity by assessing the number of cells that will allow trypan blue to enter the cell interior. The renal cell damage was measured for the different concentrations of fluoride for $24 \mathrm{~h}$ and resulted a significant decrease at 1, 2, 4 and $8 \mathrm{mM}$ concentrations $(20.13 \%, 28.5 \%, 30.88 \%$ and $38.45 \%$ respectively) compared to control group. These findings confirmed that the fluoride exposure experience renal cell damage and the cell number decrease in a dose-dependent manner. The results obtained were summarized in Figure 1. 


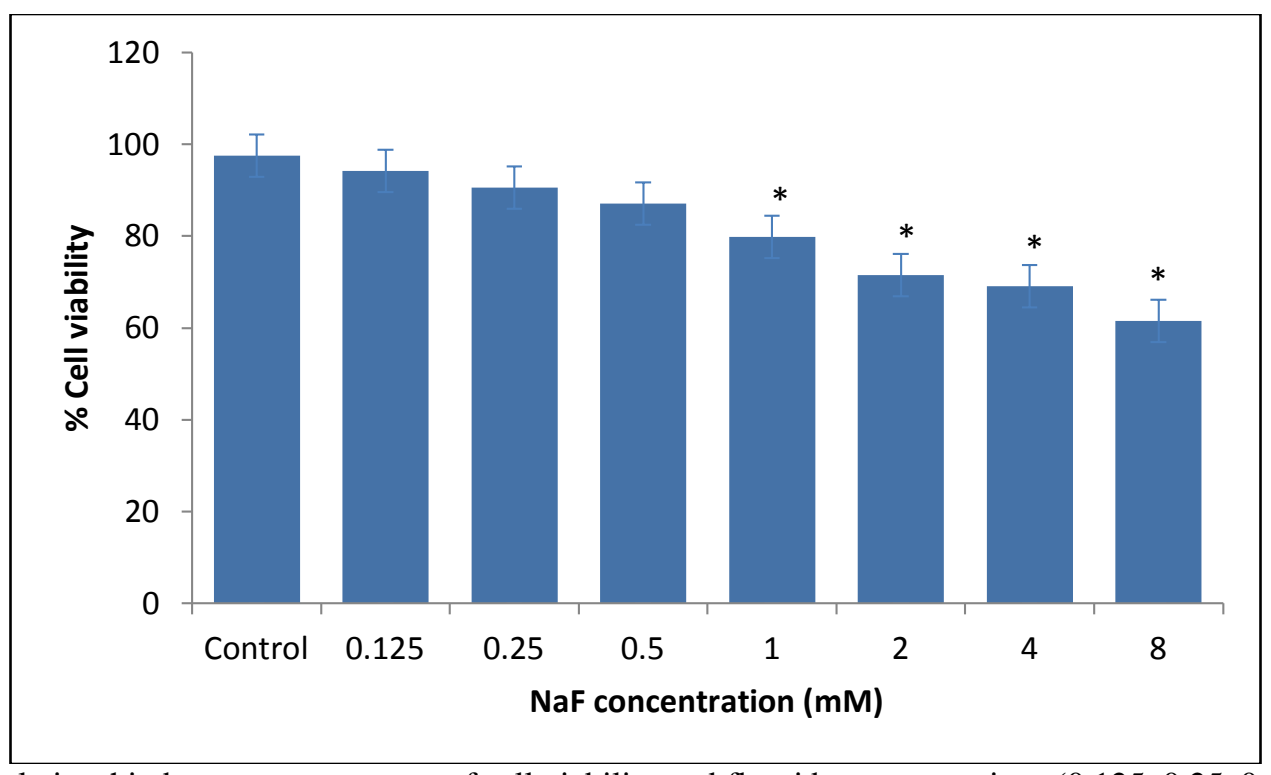

Figure 1:- Relationship between percentage of cell viability and fluoride concentrations $(0.125,0.25,0.5,1,2,4$ and $8 \mathrm{mM}$ ) of renal cells after $24 \mathrm{~h}$, assessed by Trypan blue exclusion assays. Data are expressed as mean \pm S.D,

$* \mathrm{p}<0.05$ vs control.

Increased $\mathrm{NaF}$ concentrations result in reduced mitochondrial activity in murinae renal cells:

We next used MTT assay to determine viable cells at each concentration levels based on the mitochondrial activity [Figure 2]. This resulted in a concentration-dependent decrease in mitochondrial activity in renal cells as a proxy for cell viability and further, cells treated with $8 \mathrm{mM} \mathrm{NaF}$, started to cause a significant decrease (17.52\%) in mitochondrial activity at $12 \mathrm{~h}$ compared to control group [Figure $2 \mathrm{~A}]$.

\section{Increased incubation times reduce further the activity of mitochondria in murine renal cells:}

Further the experiment was carried out to determine cell viability changes with respect to mitochondrial activity at each concentration levels with increased exposure time. By increasing the incubation time from 12 to $36 \mathrm{~h}$, the mitochondrial activity of renal cells were decreased significantly at 2,4 and $8 \mathrm{mM}(16.24 \%, 23.35 \%$ and $26.59 \%$ respectively) at 24h (Figure 2B) and 0.5, 1, 2, 4 and $8 \mathrm{mM}(13.52 \%, 14.41 \%, 21.29 \%, 25.92 \%$ and $28.94 \%$ respectively) at $36 \mathrm{~h}$ of exposure [Figure $2 \mathrm{C}$ ] in comparison with their respective control groups.

A)

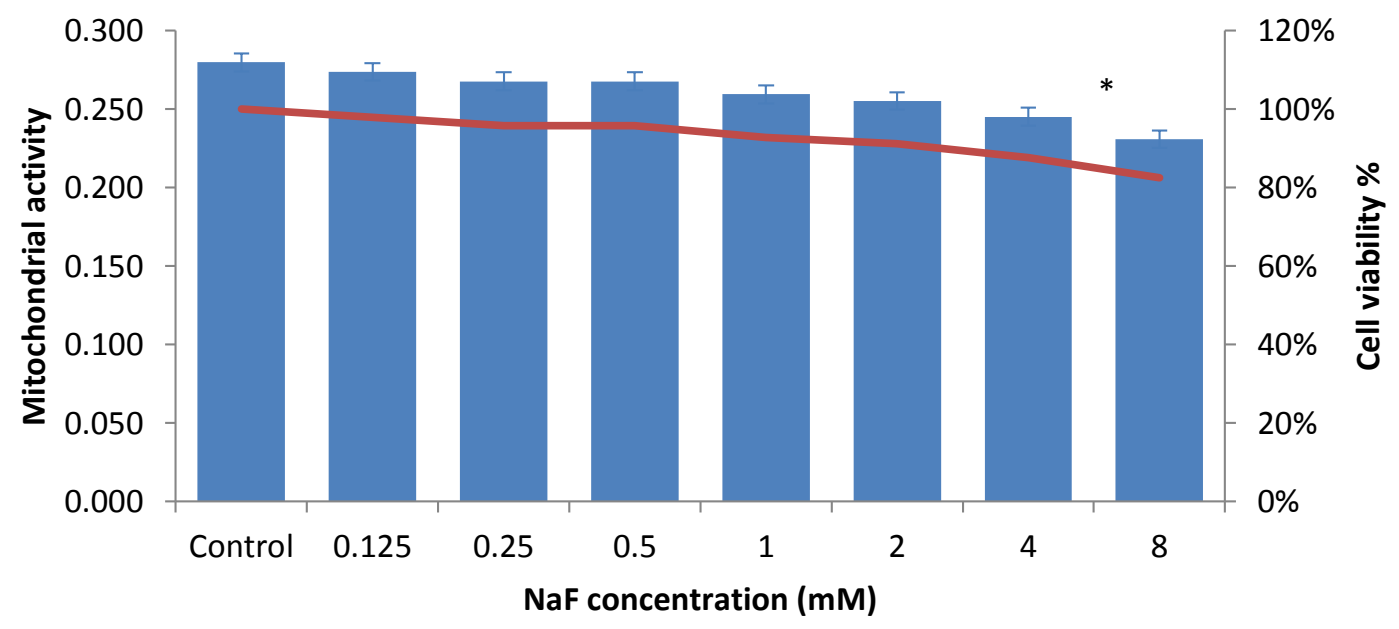


B)

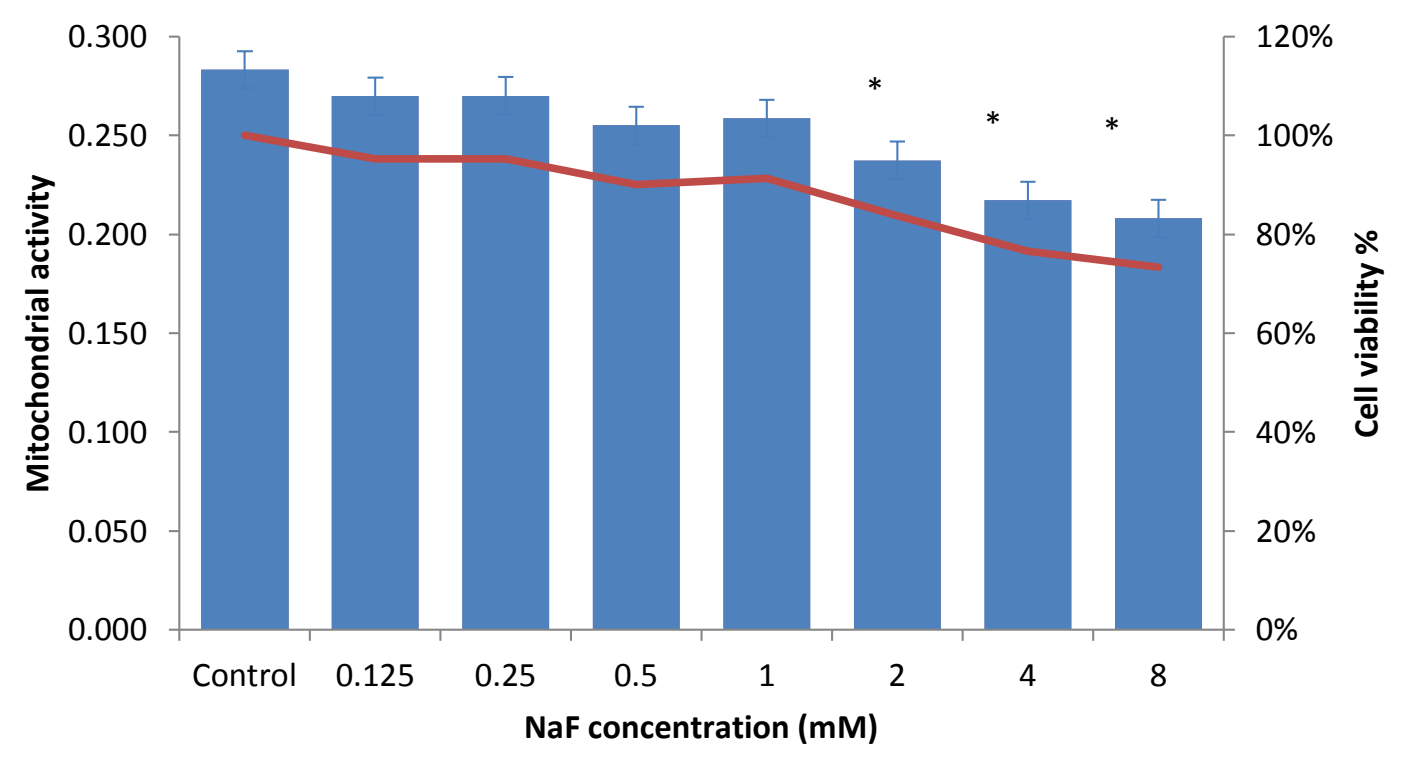

C)

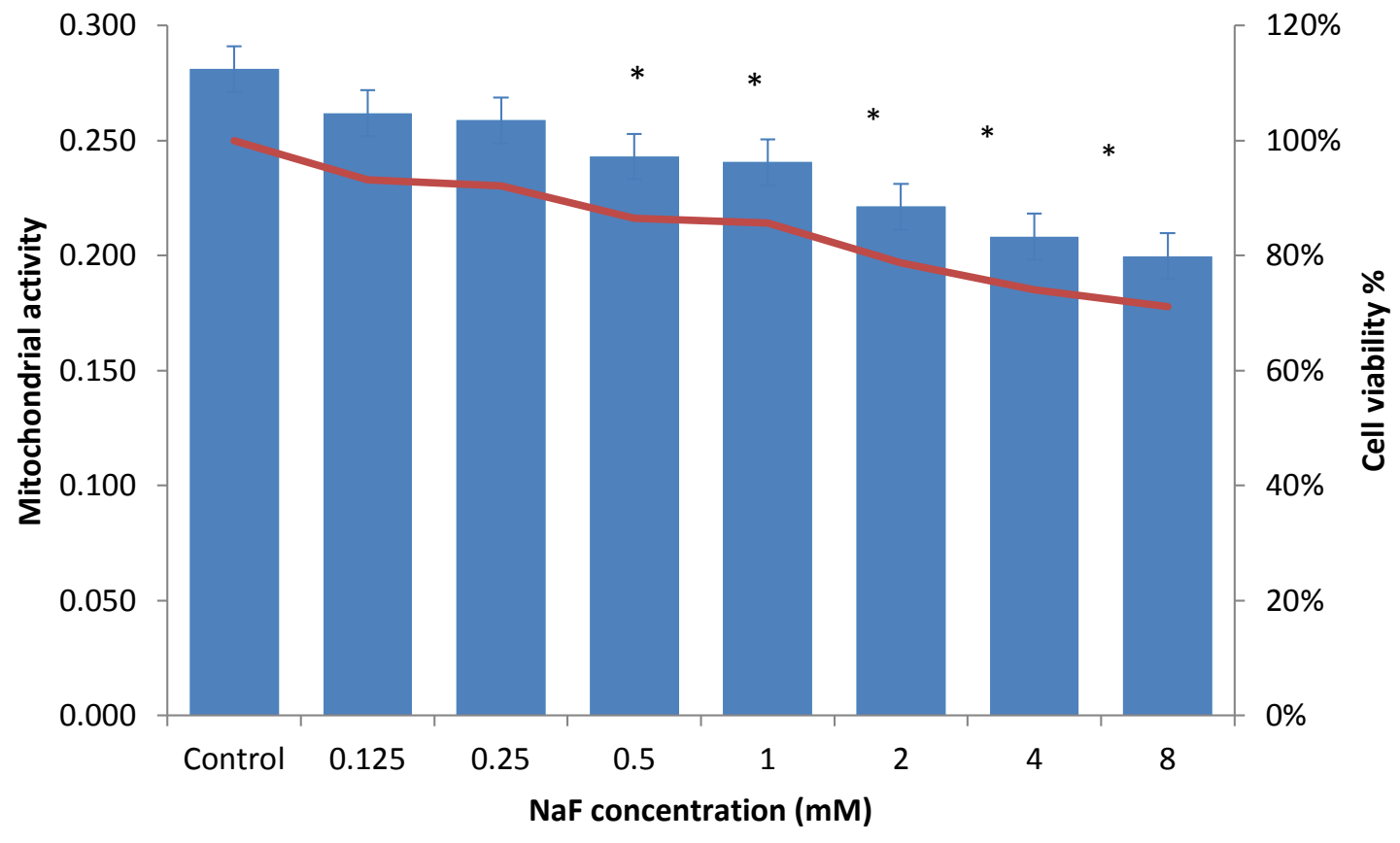

Cell viability \%

Figure 2:- Effects of fluoride on the activity of mitochondria in murinae renal cell. Cell were exposed with increasing concentrations of $\mathrm{NaF}(0.125,0.25,0.5,1,2,4$ and $8 \mathrm{mM})$ for different incubation times A) $12 \mathrm{hr}$ (B) 24hr and (C) 36hr. The activity of mitochondria in renal cells expressed as the optical density (OD) values at 570nm and $\%$ cell viability compared to control. Data are expressed as mean S.D., $\mathrm{N}=6 .{ }^{*} \mathrm{p}<0.05$ vs control. 


\section{Discussion:-}

Many studies have shown that the effect of fluoride at the cellular level [35] and this action depends upon the cell type, dose and time period of exposure [36-38]. In this study, we investigated the renal cell damage induced by different concentrations of fluoride and its concentration and time-effect on mitochondrial activity in murine renal cells.

Initially, the cell damage was evaluated by Trypan blue assay which is associated with cell membrane integrity and confirmed that the fluoride administration induced renal cell damage. Some studies have revealed that exposure to fluoride can have an effect on the kidneys including other tissues like muscle, liver, reproductive and endocrine organs by causing impairment of soft tissues [32,33,38,39]. The kidney serves as the main organ for fluoride excretion from the body [40-41] and due to its role for fluoride elimination; hence proper functioning of the kidney is vulnerable to fluoride toxicity [42]. Numerous animal studies have reported different biochemical and histopathological changes taking place in the kidney following administration of various doses of fluoride. In pigs, exposure to 100 and $250 \mathrm{mg} \mathrm{F} / \mathrm{kg}$ for 50 days have induced severe renal histological changes as well as increased renal cell apoptosis along with elevated levels of lactate dehydrogenenase activity, urea nitrogen and creatinine levels and decreased alkaline phosphatase activity [42]. In domestic chicken, high uric acid levels were observed after treatment with 10, 20 and $30 \mu \mathrm{g} / \mathrm{g}$ body weight of $\mathrm{NaF}$ for 4 weeks [33]. Basha et al [32] also reported that exposure to sodium fluoride for longer period results in necrosis in glomerules, Convolated tubules and bowman's capsule lumen in rat kidney.

Cell viability was assessed by MTT assay of which the absorbance is directly proportional to the activity of mitochondrial dehydrogenases enzyme as well as cell viability [25]. As tested by MTT, a loss of mitochondrial activity was observed in $\mathrm{NaF}$ treated cells with increasing of fluoride concentrations when compared with that of control group. At greater concentrations for a shorter period $(8 \mathrm{mM}, 12 \mathrm{~h})$, fluoride induced a significant concentration-dependent change in mitochondrial activity and for long term of exposure ( 24 and $36 \mathrm{~h}$ ), the lower concentrations may also result in a significant reduction in mitochondrial activity which was accompanied by a significant decrease in the cell number.

Mitochondria are the powerhouse of the cell, and are also the major source and target of reactive oxygen species (ROS) due to the presence of the electron transport chain within the mitochondrial inner membrane. In addition, mitochondrial DNA is more susceptible to oxidative damage than nuclear DNA due to lack of introns and protective histones [43]. Moreover oxidative stress is a well accepted mode of fluoride intoxication in many tissues and organs [36-37] and experimental evidence has indicated that exposure to fluoride results in oxidative stress both in vitro and in vivo in soft tissues such as liver [44-46], kidney [46-47], testicle [48], heart [49] etc. The increased oxidative stress is in part attributed to the dysfunctional mitochondria result in increased electron leakage from the respiratory chain during oxidative phosphorylation with a consequent generation of ROS. Kidney relies mainly on oxidativephosphorylation to provide the bulk of its energy requirements in the form of ATP for the process of tubular reabsorption [50]. Many studies have shown that fluoride clearly damages the kidney at higher concentrations [42,51,52] and according to Zhan [42], fluoride induced various degrees of damage to the architecture of proximal tubular epithelia including mitochondria. Cittanova et al [52], suggested that the mitochondria is a target for fluoride toxicity in human kidney cells due to mitochondrial abnormalities at different fluoride exposure levels. Moreover, Anuradha et al [53] showed that one of the sites of fluoride action in the kidney cells was the mitochondria via increasing oxidative stress and resulting in apoptosis. These findings also clearly demonstrated that oxidative damage is one of the mechanisms of fluoride-induced renal lesions and dysfunctions. However, further studies are needed to confirm the fluoride induced renal cell mitochondrial damage, and the prevention of these cellular lesions at grass root level will be the specific treatment through endogenous or western medicine for the renal tubulopathy in CKDu.

\section{Conclusion:-}

Fluoride induced a dose and time dependent manner renal cell damage and decreased mitochondrial activity suggests the functional impairment of mitochondria and it could be in future a valuable pharmacological target for patients with CKDu to prevent and slow-down the progression of the disease. 


\begin{abstract}
Abbreviations:
CKD: Chronic kidney disease; CKDu: Chronic kidney disease of unknown etiology; ATP: Adenosine triphosphate; MTT: 3-(4,5-dimethylthiazol-2-y1)- 2,5-diphenyl tetrazolium bromide; PBS: Phosphate buffers saline; $\alpha$-MEM: Alpha modified Minimum Essential medium; FBS: Fetal bovine serum; NaF: Sodium fluoride; ELISA: Enzymelinked immunosorbent assay; DMSO: Dimethyl sulfoxide; ANOVA: Analysis of variance; ROS: Reactive oxygen species;
\end{abstract}

\title{
Acknowledgements:-
}

The authors wish to thank all the technical officers of the department of Biochemistry, Faculty of medicine, University of Peradeniya, Sri Lanka.

\section{Funding:}

This work was performed with the supports of National Research Council, Sri Lanka (Grant No 14 - 05).

\section{Availability of data and materials:}

The datasets analyzed during the current study are available from the corresponding author on reasonable request.

\section{Authors' contributions:}

TP participated in the literature search, conduct the experiment, data extraction, data analysis, interpreting the data and preparing the manuscript. KG guided and supported to carry out the experiment. SR and NA supervised and participated in the design of the study, analysis, interpreting the data, and provided commentaries to the manuscript text. All authors read and approved the final manuscript.

\section{Ethics approval and consent to participate:}

The study protocol was approved by the Ethics Committee of Postgraduate institute of science, University of Peradeniya, Sri Lanka.

\section{Consent for publication:}

Not applicable

\section{Competing interests:}

The authors declare that they have no competing interests.

\section{References:-}

1. Gooneratne IK, Ranaweera AKP, Liyanarachchi NP, Gunawardane N, Lanerolle RD. Epidemiology of chronic kidney disease in a Sri Lankan population. Int J Diabetes Dev Ctries. 2008;28(2):60-4.

2. Gunatilake SK, Samaratunga SS, Rubasinghe RT. Chronic Kidney Disease (CKD) in Sri Lanka - Current Research Evidence Justification: A Review. Sabaragamuwa University Journal. 2014;13(2):31-58.

3. Wanigasuriya K. Aetiological factors of Chronic Kidney Disease in the North Central Province of Sri Lanka: A review of evidence to-date. Journal of the College of Community Physicians of Sri Lanka. 2012;17:1:15-20.

4. Ranasinghe H, Ranasinghe M. Status, Gaps and Way Forward in Addressing the Chronic Kidney Disease Unidentified (CKDu) in Sri Lanka. Journal of Environmental Professionals Sri Lanka. 2015:4:2:58-68.

5. Redmon JH, Elledge MF, Womack DS, Wickremashinghe R, Wanigasuriya KP, Peiris-John RJ, Lunyera J, Smith K, Raymer JH, Levine KE. Additional perspectives on chronic kidney disease of unknown aetiology $(\mathrm{CKDu})$ in Sri Lanka - lessons learned from the WHO CKDu population prevalence study. BMC Nephrol. 2014;15:125.

6. Chung S, Koh ES, Shin SJ, Park CW. Malnutrition in patients with chronic kidney disease. Open Journal of Internal Medicine. 2012;2:89-99.

7. Handunnetti D, Daniel S. Conflicting reports highlight scientific data gaps in Sri Lanka's chronic kidney disease. Sci Dev Net. 2012.

8. Presidential task force. 2015. http://www.presidentialtaskforce.gov.lk/en/kidney.html

9. Elledge MF, Redmon JH, Levine KE, Wickremasinghe RJ, Wanigasariya KP, Peiris-John RJ. Chronic Kidney Disease of Unknown Etiology in Sri Lanka: Quest for Understanding and Global Implications. RTI International. 2014. 
10. Dissanayake CB. Water quality in the dry zone of Sri Lanka - Some interesting health aspects. J Natn Sci Found Sri Lanka. 2005;33(3):161-8.

11. Dharmaratne RW. Fluoride in drinking water and diet: the causative factor of chronic kidney diseases in the North Central Province of Sri Lanka. Environ Health Prev Med. 2015;20:237-42.

12. Jayawardana DT, Pitawala HMTGA, Ishiga H. Geochemical evidence for the accumulation of vanadium in soils of chronic kidney disease areas in Sri Lanka. Environ Earth Sci. 2015;73(9):5415-24.

13. Wimalawansa SA, Wimalawansa SJ. Agrochemical-Related Environmental Pollution: Effects on Human Health, Global journal of biology. Agriculture and health sciences. 2014;3(3):72-83.

14. Nanayakkara S, Komiya T, Ratnatunga N, Senevirathna STMLD, Harada KH, Hitomi T, Gobe G, Muso E, Abeysekera T, Koizumi A. Tubulointerstitial damage as the major pathological lesion in endemic chronic kidney disease among farmers in North Central Province of Sri Lanka. Environ Health Prev Med. 2012;17:21321.

15. Nanayakkara S, Senevirathna STMLD, Karunaratne U, Chandrajith R, Harada KH, Hitomi T, Watanabe T, Abeysekera T, Aturaliya TNC, Koizumi A. Evidence of tubular damage in the very early stage of chronic kidney disease of uncertain etiology in the North Central Province of Sri Lanka: a cross-sectional study. Environ Health Prev Med. 2012;17:109-17.

16. Wijetunge S, Ratnatunga NVI, Abeysekera DTDJ, Wazil AWM, Selvarajah M, Ratnatunga CN, Retrospective analysis of renal histology in asymptomatic patients with probable chronic kidney disease of unknown aetiology in Sri Lanka.Ceylon Med J. 2013;58:142-7.

17. Athuraliya NTC, Abeysekera TDJ, Amerasinghe PH, Kumarasiri R, Bandara P, Karunaratne U, Milton AH, Jones AL. Uncertain etiologies of proteinuric-chronic kidney disease in rural Sri Lanka. Kidney Int. 2011;80:1212-21.

18. Cha M, Han S, Son SM, Hong H, Choi Y, Byun J, Mook-Jung I. Mitochondria Specific Accumulation of Amyloid b Induces Mitochondrial Dysfunction Leading to Apoptotic Cell Death. PLoS ONE. 2012;7(4):e34929.

19. Ohba H, Kanazawa M, Kakiuchi T, Tsukada H. Effects of acetaminophen on mitochondrial complex I activity in the rat liver and kidney: a PET study with 18F-BCPP-BF, EJNMMI Research. 2016;6:82.

20. Che R, Yuan Y, Huang S, Zhang A. Mitochondrial dysfunction in the pathophysiology of renal diseases. Am J Physiol Renal Physiol. 2013;306:F367-F78.

21. Shoubridge EA, Wai T. Mitochondrial DNA and the Mammalian Oocyte. Curr Top Dev Biol. 2007;77:87-111.

22. Emma F, Bertini E, Salviati L, Montini G. Renal involvement in mitochondrial cytopathies. PediatrNephrol. 2012;27:539-50.

23. Cavero T, Rabasco C, Molero A, Blazquez A, Hernandez E, Martin MA, Praga M. When should a Nephrologist suspect a mitochondrial disease?. Nefrologia. 2015;35(1):6-17.

24. Emma F, Montini G, Salviati L, Dionisi-Vici C. Renal Mitochondrial Cytopathies. Int J Nephrol. 2011.

25. Siqueira P, Magalhães A, Pires W, Pereira F, Lacerda S, Carrião M, Bakuzis A, Costa C, Lopes L, Estrela C. Cytotoxicity of glass ionomer cements containing silver nanoparticles. J Clin Exp Dent. 2015;7(5):622-7.

26. Strober W. Trypan Blue Exclusion Test of Cell Viability. CurrProtoc Immunol. 1997;A.3B.1-A.3B.2.

27. Mosmann T. Rapid Colorimetric Assay for Cellular Growth and Survival: Application to Proliferation and Cytotoxicity Assays. J Immunol Methods. 1983;65:55-63.

28. Byun JW, Choo SH, Kim HH, Kim YJ, Hwang YJ, Kim DY. Evaluation of Boar Sperm Viability by MTT Reduction Assay in Beltsville Thawing Solution Extender. Asian-Aust J Anim Sci. 2008;21(4):494-8.

29. Denizot F, Lang R. Rapid colorimetric assay for cell growth and survival Modifications to the tetrazolium dye procedure giving improved sensitivity and reliability. J Immunol Methods. 1986;89:271-7.

30. Aziz DM. Assessment of bovine sperm viability by MTT reduction assay. AnimReprod Sci. 2006;92:1-8.

31. Chandrajith R, Dissanayake CB, Ariyarathna T, Herath HMJMK, Padmasiri JP. Dose-dependent Na and Ca in fluoride-rich drinking water - Another major cause of chronic renal failure in tropical arid regions. Sci Total Environ. 2011;409:671-675.

32. Basha SK, Rao KJ. Sodium fluoride induced histopathalogical changes in liver and kidney of albino mice. Acta Chim Pharm Indica. 2014;4(1):58-62.

33. Anjum KM, Mughal MS, Sayyed U, Yaqub A, Khalique A, Rashid MA, Yousaf MZ, Mumataz N. Influence of increasing fluoride dose rates on selected liver and kidney enzymes profile in domestic chicken (Gallus domesticus). J Anim Plant Sci. 2014;24(1):77-80.

34. Avelar-Freitas BA, Almeida VG, Pinto MCX, Mourao FAG, Massensini AR, Martins-Filho OA, Rocha-Vieira E, Brito-Melo GEA. Trypan blue exclusion assay by flow cytometry. Braz J Med Biol Res. 2014;47(4):307-15.

35. Silbergeld EK. Toxicology", Encyclopaedia of occupational health and safety, Chapter 33, Fourth edition. 
36. Agalakova NI, Gusev GP. Molecular Mechanisms of Cytotoxicity and Apoptosis Induced by Inorganic Fluoride. ISRN Cell Biology. 2012.

37. Barbier O, Arreola-Mendoza L, Razo LM. Molecular mechanisms of fluoride toxicity. Chem Biol Interact. 2010;188:319-33.

38. Perera T, Ranasinghe S, Alles N, Waduge R. Effect of fluoride on major organs with the different time of exposure in rats. Environ Health Prev Med. 2018;23:17

39. Shashi A, Thapar SP. Histopathology of fluoride-induced hepatotoxicity in rabbits. Fluoride. 2000;34(1):34-42.

40. Martinez-Mier EA. Fluoride: Its Metabolism, Toxicity, and Role in Dental Health. Evid Based Complement Alternat Med. 2011.

41. Kono K, Yoshida Y, Watanabe M, Tanimura Y, Hirota T. Urinary Fluoride excretion in Fluoride exposed Workers with Diminished Renal Function. Ind Health. 1984;22:33-40.

42. Zhan X, Wang M, Xu Z, Li J. Toxic effects of fluoride on kidney function and histological structure in young pigs. Fluoride. 2006;39(1):22-26.

43. Ishimoto Y, Inagi R. Mitochondria: a therapeutic target in acute kidney injury. Nephrol Dial Transplant. 2016;31:1062-9.

44. Guo X, Sun G, Sun Y. Oxidative stress from fluoride-induced hepatotoxicity in rats. Fluoride. 2003;36(1):25-9.

45. Lu Y, Luo Q, Cui H, Deng H, Kuang P, Liu H, Fang J, Zuo Z, Deng J, Li Y, Wang X, Zhao L. Sodium fluoride causes oxidative stress and apoptosis in the mouse liver. AGING. 2017;9(6).

46. Ranjan R, Swarup D, Patra RC. Oxidative stress in erythrocytes, liver, and kidneys of F-exposed rabbits. Fluoride. 2009;42(2):88-93.

47. Luo Q, Cui H, Deng H, Kuang P, Liu H, Lu Y, Fang J, Zuo Z, Deng J, Li Y, Wang X, Zhao L. Histopathological findings of renal tissue induced by oxidative stress due to different concentrations of fluoride. Oncotarget, 2017, 8(31), pp. 50430-50446.

48. Ghosh D, Das S, Maiti R, Jana D, Das UB. Testicular toxicity in sodium fluoride treated rats: association with oxidative stress. ReprodToxicol. 2002;16(4):385-90.

49. Nabavi SF, Nabavi SM, Ebrahimzadeh MA, Eslami SH, Jafari N, Moghaddam AH. The protective effect of curcumin against sodium fluoride-induced oxidative stress in rat heart. Arch Biol Sci Belgrade. 2011;63(3):563569.

50. Soltoff SP. ATP and the regulation of renal cell function. Ann Rev Physiol. 1986;48:9-31.

51. Song C, Cao X, Yang Z, Guo S, Shang Z. F-induced cell cycle arrest, apoptosis, and DNA changes in TM3 mouse Leydig cells. Fluoride. 2013;46(4):218-223.

52. Cittanova M, Lelongt B, Verpont M, Geniteau-Legendre M, Wahbe F, Prie D, Coriat P, Ronco P. Fluoride ion toxicity in human kidney collecting duct cells. Anesthesiology. 1996;84:428-35.

53. Anuradha CD, Kanno S, Hirano S. Oxidative damage to mitochondria is a preliminary step to caspase-3 activation in fluoride-induced apoptosis in HL-60 cells. Free Radic Biol Med. 2001;1;31(3):367-73. 